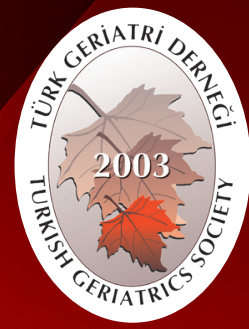

Turkish Journal of Geriatrics DOI: $10.31086 /$ tigeri.2018.66 2018;21 (4):588-595

- Türkan KARACA ${ }^{1}$

- Semiha AYDIN ÖZKAN²

- Emine DERYA ISTER ${ }^{1}$

CORRESPONDANCE

Türkan KARACA

Adıyaman University, Nursing Deparment,

Adiyaman, Turkey

Phone: 04162230023

e-mail: turkan_20051@hotmail.com

Received: 08/07/2018

Accepted: 27/10/2018

Adıyaman University, Nursing Deparment,

Adıyaman, Turkey

Adıyaman University, Midwifery Department, Adıyaman, Turkey

Presented at the $23^{\text {rd }}$ World Nursing and Healthcare Conference,

Berlin Germany
RESEARCH

\section{PHYSICAL RESTRAINT USE IN ELDERLY PATIENTS: PERCEPTIONS OF NURSES IN UNIVERSITY HOSPITALS}

\section{Abstract}

Introduction: Nurses are primarily responsible for patient care and safety. Identification of nurses perceptions about restraint practices is thus important for raising awareness on this issue. This study aimed to identify perceptions about physical restraint use among nurses working in wards and intensive care units (ICUs) in three university hospitals.

Materials and Method: The study was conducted in three university hospitals with 298 nurses who completed the Perceptions of Restraint Use Questionnaire (PRUQ) to evaluate their perceptions of the use of restraint in the care of older patients. Higher values indicated that the situations described were considered an important justification for using physical restraints.

Results: The overall mean score for the PRUQ was 4.14. Nurses identified "Falling out of bed" as the most important reason for restraining a patient and "Substituting for staff observation"as the least important reason. In addition, there was a significant relationship between the perception of using restraints in wards and ICUs. It was noted that the nurses reported that using restraints in ICUs was more common than in wards.

Conclusion: The nurses' perceptions on the practice of physical restraint were high. According to these result, the nurses need to learn alternative practices for decreasing use of restraints and consider it important to plan individualized nursing care for older patients who need to be restrained and to provide sufficient information to them and their families about the safety charestics of the practice.

Keyword: Restraint, Physical; Aged; Nurses

ARAŞTIRMA

\section{YAŞLI HASTALARDA FIZIKSEL TESPIT KULLANIMI: ÜNIVERSITE HASTANELERINDE ÇALIŞAN HEMŞIRELERIN FiZIKSEL TESPIT KULLANIM ALGILARI}

\section{$\ddot{O}_{z}$}

Giriş: Hemşirelerin temel sorumluluklarından biri de bakım sürecinde hastaların kendilerine ve başkalarına zarar vermesini engellemektir. Hemşirelerin tespit uygulamalarındaki algı düzeylerinin tanımlanması bu konuda farkındalık oluşturmak açısından önemlidir. Bu çalışmada üç üniversite hastanesinde çalışan hemşirelerin genel servisler ile yoğun bakımlarda fiziksel tespit kullanımına ilişkin algılarının incelenmesi amaçlanmıştır.

Gereç ve Yöntem: Bu çalışma, hemşirelerin yaşı hastaların bakımında tespit kullanımı hakkındaki görüşlerini değerlendirmek amacıyla üç üniversite hastanesinde Tespit Kullanımı Algı Anketini (PRUQ-T) tamamlayan 298 hemşire ile yürütülmüştür. Anketten elde edilen puanların yükselmesi hemşirelerin fiziksel tespiti kullanım algılarının yüksek olduğunu göstermektedir.

Bulgular: PRUQ-T puan ortalaması 4.14 olarak bulunmuştur. Hemşireler, hastalara tespit kullanımının en önemli nedenini "Hastanın yataktan düşmesini engellemek", en az önemli nedenini ise "Personelin gözetimi için yaşlının yerinde kalmasını sağlama" olarak belirtmişlerdir. Ayrıca, genel servislerde tespit kullanımı algısı ile yoğun bakım ünitelerinde lerinde tespit kullanımı algısı arasında istatistiksel olarak anlamlı bir fark bulunmuştur. Hemşireler yoğun bakım ünitelerinde servislere göre daha fazla tespit kullanıldığını belirtmişlerdir.

Sonuç: Çalışmamızda hemşirelerin tespit kullanım algılarının yüksek olduğu saptanmıştır. Bu sonuca göre, hemşirelerin yaşıllarda tespit kullanımının azaltılması için tespit kullanımına alternatif yöntemler uygulaması, tespit kullanılması gereken durumlarda ise bireyselleştirilmiş hemşirelik bakım planı yapması ve güvenlik uygulamalarına ilişkin hastalara ve ailelerine yeterli bilgi verilmesi önerilerilmektedir.

Anahtar sözcükler: Fiziksel tespit; Yaşlı; Hemşire 


\section{INTRODUCTION}

One of the fundamental responsibilities of nurses is to prevent patients from harming themselves and others in the care process (1). Nurses may have to make the decision themselves to use restraints to protect patients and others. Physical restraints are defined as the use of physical and mechanic tools or chemical agents that limit movements of some parts of the body for the control of physical activities with a view to prevent individuals from harming themselves or others (2-4). Another definition includes restricting or preventing patient movements by use of physical or mechanical devices or using bodily force of a health professional for a short time (5-7).

Although restraints inevitably limit individuals' movements, they prevent them from harming themselves or others. Beside the existing physiopathological problems of elderly people in nursing homes and wards for the elderly, a large number of them experience various changes in their cognitive levels and behaviors. These eldery patients might poorly adjust to treatment processes, leading them to harm themselves (1). A study on this issue reports that $80 \%$ of the elderly people in the ICUs experience cognitive and behavioral agitation at various levels and harm themselves by removing endotracheal or tracheostomy tubes or dressings (8). In another study that investigated restraint use in an education and research hospital in Australia, Irving et al. reported the prevalence of restraint use as $9.4 \%$, with $62 \%$ of these involving confinement to the bed, $17 \%$ involved chemical restrainment, and $3.9 \%$ involved the use of a restraint vest. The same study revealed that more than one restraint method was used for $25 \%$ of the patients and restraint use increased with the increase in age. The prevalence of restraint use was $31 \%$ in patients aged over 85 years but only $14.1 \%$ in patients aged between 75 and 85 years (9). In these cases, limiting movements and using restraint could become a part of the treatment. In cases where patients harm themselves or others, nurses see limiting movements and using restraints as part of care.
Nurses are primarily responsible for patient care and safety. Identification of their perceptions about restraint practices is thus important for raising awareness on this issue and protecting eldery people from unnecessary damage of using physical restraint. This study aimed to identify perceptions about physical restraint use among nurses who work in university hospitals and to investigate whether there are differences between wards and ICUs in terms of the perceptions of restraint use.

\section{Background}

Review of the related literature indicates that individuals' perceptions about restraint use in the elderly are identified via the Perceptions of Restraint Use Questionnaire (PRUQ) developed by Strumpf and Evans (1993) (10). One of the pioneer studies that utilized the PRUQ included 18 nurses providing care for 20 patients. The most important reason for restraint use by nurses in that study was found to be the protection of patients' and others' safety (11). An analysis of the studies conducted in different clinics that utilized the PRUO tool indicate that some facts in physical restraint use were found to be more important and acceptable than others for enhancing patient safety $(12,13)$. In a study with 52 nurses in three different clinics (Internal Diseases, Orthopedics, and Cardiovascular Surgery), Helmuth found that patient safety was the most important reason for using restraint and achievement of quiet time was the least important (12). Myers reported that the most important reason for physical restraint use in their environment was preventing patients from falling and the least important was the need for quiet time (13).

In their study conducted with 94 nurses, McGabe et al. utilized the PRUQ and found the mean score was 2.8 out of 5 and that treatment interference was reported to be the most important restraint reason (14). Similarly, nurses' physical restraint perception mean score was found to be 2.8 in a study conducted by Matsui in Japan (15). In this study conducted with a sample of 205 nurses, perceptions' mean score for physical restraint use in surgery wards were found to 
be significantly higher than in other wards, and the most important reason was stated as preventing patients from breaking open sutures.

A study that utilized the PRUQ conducted by Lopez et al. with 19 Spanish nurses working in nursing homes found the general mean scores to be 3.4 out of 5. In addition, no significant differences were found between nurses' perceptions of restraint use and demographic charestics of the working units (16).

A study that utilized the PRUQ to investigate nursing students' restraint use perceptions found that the students initially had negative attitudes about restraint use. However, they were found to adjust this to positive attitudes as they observed the clinic nurses' need for the use of restraint (17).

This review of the studies on this subject conducted in various countries and various clinics led to the conclusion that perceptions of and primary reasons for restraint use vary. The common opinion held by the workers in the field is that restraint should be used primarily for patient safety. We could not find other studies in our country that have aimed to identify nurses' perceptions about restraint use. Therefore, the purpose of the present study was two-fold: to examine nurses' perceptions about restraint use and to identify the relationship between wards and intensive care nurses' perception about restraints. It was anticipated that the results would provide an evaluation of the current situation, identify the needs in this field, and make a contribution to the literature.

\section{MATERIALS AND METHOD}

\section{Sample selection}

This cross-sectional study was conducted between September and October, 2017. The target population of the study was nurses working in three university hospitals located in the south eastern part of Turkey who provided care for the elderly in internal and surgery wards and ICUs. Five hundred nurses (except pediatric, emergency and policlinic nurses) in these three university hospitals were the target population for the study. The number of participants was identified using power analysis in the 3.1.7 version of the G-Power program, in which the confidence interval was taken as $95 \%$, the error margin as $5 \%$, the effect size as 0.20 , and the power of research as $80 \%$ (18). The result of this analysis, the number of participants was identified as 262 . The number of ward nurses (Internal Diseases, Neurosurgery, Thoracic diseases, Neurology), and intensive care nurses (Palliative care, Reanimation IC, Cardiology IC, Neurosurgery IC, Internal Diseases IC) who participated in the study were 148 and 150 respectively (Total 298 ).

\section{Data collection instruments}

The data were collected using the Descriptive Characteristics Form and the PRUQ.

Descriptive characteristics form. For the purpose of this study, this form was prepared to obtain the subjects' age, gender, number of years of working experience, number of years in the current work unit, identity of the current work unit, and education in geriatrics nursing.

The Perceptions of Restraint Use Questionnaire (PRUQ) A Turkish form of Strumpf and Evans's PRUQ tool was developed to collect study data (11). The tool consists of 17 items, each with a 5-point Likert response scale and each consisting of a reason for physical restraint. Participants scale their perception of the importance of physical restraint use for each itemized purpose. The total score for each subject ranging from 17 to 85 is reduced to an average score between 1 and 5, in which a higher average indicates a more favorable overall perception towards physical restraint use with older adults.

The Cronbach's Alpha Reliability Coefficient value analysis for the original questionnaire was 0.93 . When the Turkish form of the 17-item PRUO was developed, the Cronbach alpha reliability coefficient was 0.92 (19).

\section{Ethical considerations}

Prior to the study, ethics committee approval was obtained from the Biomedical Research Ethics 
Committee of the university (permission no: 20176-17) and the institutions where the study was conducted. After the nurses who participated in the study were informed about the purpose of the study, they were informed that the decision to participate in the study belonged only to them, that they should not write their name on the questionnaire, that the data to be collected would be used only within the scope of the study, and that confidentiality would be strictly maintained. Once their consent was obtained, the personal data form and the PRUQ were distributed for completion.

\section{Data analysis}

The data obtained from the study were analyzed in SPSS 16.00 package programme, and theirnormality was tested using Kolmogorov-Smirnov and ShapiroWilk tests. Parametric tests were used because the PRUQ scale displayed normal distribution. The data were displayed in tables as means $( \pm)$, standard deviations (SDs), and numbers and percentages of the individuals. Data were assessed by descriptive statistics, t-tests and One way Anova. A p value $<0.05$ was considered statistically significant.

\section{RESULTS}

Of all the nurses participating in the study, 215 (72.1\%) were female and $83(27.9 \%)$ were male. The average age of the participants was $30.48 \pm 5.55$ years (youngest 20 years, oldest 47 years), and the total number of years of experience was $8.20 \pm 5.65$ years (least 1 year, most 27 years). There were $45.8 \%$ (136) nurses who stated that they had received education in geriatric nursing.

The nurses' perception of the use of restraint displayed similar distribution between the groups in terms of variables such as gender, age group, years of experience, and receiving geriatrics education or not. There is a statistically significant difference between PRUO mean score of the nurses according to their gender, age and their years of experience $(p<0.05)$. There is no significant difference between PRUQ mean score of the nurses according to receiving geriatrics education status ( $p>0.05$ ) (Table 1).

Table 1. Distribution of the PRUQ mean scores for descriptive characteristics.

\begin{tabular}{|c|c|c|}
\hline Descriptive characteristics & $\mathrm{n}(\%)$ & PRUQ Mean \pm sd \\
\hline \multicolumn{3}{|l|}{ Gender (298) } \\
\hline Female & $215(72.1)$ & $4.18 \pm 0.60$ \\
\hline Male & $83(27.9)$ & $4.03 \pm 0.57$ \\
\hline Statistics* & & $t=-2.034, p=0.040$ \\
\hline \multicolumn{3}{|l|}{ Age (298) } \\
\hline $20-29$ & $156(52.3)$ & $4.06 \pm 0.64$ \\
\hline $30-39$ & $121(40.6)$ & $4.18 \pm 0.54$ \\
\hline$\geq 40$ years old & $21(7.0)$ & $4.48 \pm 0.40$ \\
\hline Statistics ${ }^{\star \star}$ & & $F=5.064, p=0.007$ \\
\hline \multicolumn{3}{|l|}{ Years of experience (295) } \\
\hline $1-5$ years & $126(42.3)$ & $4.05 \pm 0.69$ \\
\hline $6-10$ years & 95 (31.9) & $4.16 \pm 0.51$ \\
\hline$>10$ years & $74(24.8)$ & $4.26 \pm 0.50$ \\
\hline Statistics** & & $F=3.069, p=0.048$ \\
\hline \multicolumn{3}{|l|}{ Geriatrics education (298) } \\
\hline Yes & $136(45.8)$ & $4.07 \pm 0.63$ \\
\hline No & $162(54.4)$ & $4.20 \pm 0.56$ \\
\hline Statistics* & & $t=-1.847 p=0.066$ \\
\hline
\end{tabular}

*Independent sample t test; ${ }^{* \star O n e ~ w a y ~ A n o v a ~}$ 
Table 2. Distribution of PRUQ mean scores for restraint reasons.

\begin{tabular}{lcc}
\hline PRUQ & Mean & sd \\
\hline 1- Protecting an older person from: & 4.55 & 0.60 \\
a- Falling out of bed & 4.37 & 0.83 \\
b- Falling out of a chair & 4.37 & 3.75 \\
c- Unsafe ambulation & 3.37 \\
2- Preventing an older person from wandering & 4.36 & 1.01 \\
3- Preventing an older person from taking things from others & 3.94 \\
4- Preventing an older person from getting into dangerous places or supplies & 1.37 \\
5- Keeping a confused older person from bothering others & 0.75 \\
6- Preventing an older person from: & 4.45 \\
a- Pulling out a catheter & 4.43 \\
b- Pulling out a feeding tube & 4.26 \\
c- Pulling out an IV & 4.31 \\
d- Breaking open sutures & 4.28 \\
- Removing a dressing & 3.75 \\
7- Providing quiet time or rest for an overactive older person & 4.20 \\
8- Providing for safety when judgment is impaired & 3.54 \\
9- Substituting for staff observation & 4.21 \\
10- Protecting staff or other patients from physical abusiveness/combativeness & 0.75 \\
11- Managing agitation & 4.23 \\
\hline Total PRUQ score & $\mathbf{4 . 1 4}$ \\
\hline
\end{tabular}

Table 3. Distribution of the PRUQ mean scores for subjects in wards and ICUs.

\begin{tabular}{|c|c|c|c|}
\hline PRUQ & $\begin{array}{r}\text { Wards } \\
\text { Mean } \pm \text { sd }\end{array}$ & $\begin{array}{r}\text { ICUs } \\
\text { Mean } \pm \text { sd }\end{array}$ & p value* \\
\hline \multicolumn{4}{|l|}{ 1- Protecting an older person from: } \\
\hline a- Falling out of bed & $4.51 \pm 0.69$ & $4.59 \pm 0.49$ & 0.211 \\
\hline b- Falling out of a chair & $4.28 \pm 0.94$ & $4.45 \pm 0.70$ & 0.078 \\
\hline c- Unsafe ambulation & $4.30 \pm 0.82$ & $4.43 \pm 0.82$ & 0.176 \\
\hline 2- Preventing an older person from wandering & $3.63 \pm 0.94$ & $3.87 \pm 1.07$ & 0.042 \\
\hline 3- Preventing an older person from taking things from others & $3.05 \pm 1.43$ & $3.68 \pm 1.28$ & 0.001 \\
\hline 4- Preventing an older person from getting into dangerous places or supplies & $4.28 \pm 0.82$ & $4.43 \pm 0.67$ & 0.085 \\
\hline 5- Keeping a confused older person from bothering others & $3.66 \pm 1.10$ & $4.21 \pm 0.83$ & 0.001 \\
\hline \multicolumn{4}{|l|}{ 6- Preventing an older person from: } \\
\hline a- Pulling out a catheter & $4.32 \pm 0.91$ & $4.58 \pm 0.52$ & 0.003 \\
\hline b- Pulling out a feeding tube & $4.38 \pm 0.77$ & $4.48 \pm 0.72$ & 0.240 \\
\hline c- Pulling out an IV & $4.13 \pm 0.92$ & $4.38 \pm 0.71$ & 0.009 \\
\hline d- Breaking open sutures & $4.28 \pm 0.83$ & $4.34 \pm 0.76$ & 0.543 \\
\hline e- Removing a dressing & $4.20 \pm 0.82$ & $4.36 \pm 0.72$ & 0.067 \\
\hline 7- Providing quiet time or rest for an overactive older person & $3.58 \pm 1.08$ & $3.91 \pm 1.01$ & 0.008 \\
\hline 8- Providing for safety when judgment is impaired & $3.99 \pm 1.01$ & $4.41 \pm 0.68$ & 0.001 \\
\hline 9- Substituting for staff observation & $3.46 \pm 1.16$ & $3.62 \pm 1.24$ & 0.249 \\
\hline $\begin{array}{l}\text { 10- Protecting staff or other patients from physical abusiveness/ } \\
\text { combativeness }\end{array}$ & $4.08 \pm 0.99$ & $4.34 \pm 0.78$ & 0.012 \\
\hline 11- Managing agitation & $4.14 \pm 0.92$ & $4.33 \pm 0.76$ & 0.051 \\
\hline Total PRUQ score & $4.02 \pm 0.61$ & $4.26 \pm 0.56$ & 0.001 \\
\hline
\end{tabular}

* Independent sample t test 
The overall average PRUQ score for this study was found to be 4.14 out of a total of 5 points. The most important reasons for restraint use indicated by nurses included protecting an older person from falling out of bed, preventing an older person from breaking open sutures, and pulling out a catheter and/or a feeding tube. Relatively less important reasons for nurses included preventing an older person from taking others' goods, acting as a substitution for staff observation, and providing quiet time in the ward or ICU (Table 2).

There was a significantly difference between the average scores of ward nurses' perceptions (4.02) and those of ICU nurses (4.26) $(p<0.05)$ In addition to this result, the PRUQ mean scores of nurses working in ICUs were found to be higher for all reasons (Table 3 ).

\section{DISCUSSION}

Use of restraint on eldery patients is one of the important cases that causes ethical dilemma because it limits the individual's autonomy and independence. Routine care practices should be regulated in a way restraint would be needed at minimum level. However, its indications, expected benefits, risks and potential complications should be considered well in cases when restraint needs to be used. Nurses use physical restraints as useful and simple solutions to prevent treatment interference. However, the use of restraints that violate physical, psychological, legal, ethical, and/ or moral boundaries are considered intrusive and risky and are only legally permitted in very specific circumstances.

Our study showed that there was a significant relationship between the perception of using restraints in wards and ICUs. According to the results, using restraints in ICUs was more common than in wards, despite the reported potential harm to the eldery patients and the controversy concerning the effectiveness of physical restraints (18).
The mean scores that the nurses obtained from the perceptions of the restraint use questionnaire suggest that nurses currently hold a very strong belief that restraints should be used with older people for the reasons given in the scale. However, it is important to consider whether understanding the dangers of restraint as well as learning how to "make sense" of the patients' behaviors as a communication of distress or unmet need would significantly decrease their mean scores. Results similar to ours were found in a study that also aimed to identify - ward and ICU nurses' restraint perceptions. The reason given for this was that ICUs are more complicated than other wards, and more emergency cases are managed there (20). It could also be due to the fact that as intensive care nurses spend more time with their ICU patients than the practice in other nursing situations, these nurses could be more worried about patient safety and thus tend to use more restraints.

Nurses who work in wards and in ICUs considered the use of physical restraints more important in some circumstances: both groups supported its use for protecting an older person from falling out of bed. Other studies that utilized the PRUQ also identified patient safety as the primary reason $(12,13,16)$. However, studies have shown that no evidential information has been reported that restraint use provides patient safety $(20,21)$.

The other reasons for which our subjects considered the use of restraint to be important (preventing an older person from breaking sutures open and pulling out a catheter or a feeding tube) were confirmed by several studies $(15,16,20,22,23)$. In routine patient care, restraint use should be one of the least frequently applied practices by nurses. For instance, restraint use should be avoided in a patient who constantly removes the dressing, and the case should be managed using alternative methods. Various studies posit that restraint 
should be used only in terminally ill patients to protect dressings and prevent from the removal of tubes $(24,25)$.

The findings about the use of physical restraint for preventing an older person from taking things from others, substituting for staff observation, and providing quiet time were also reported in other studies $(16,20)$.

There is a statistically significant difference between PRUQ mean score of the nurses according to their gender, age and their years of experience $(p<0.05)$. There is no significant difference between PRUQ mean score of the nurses according to receiving geriatrics education status ( $p>0.05)$. Some other studies investigating this issue provided similar findings $(13,16)$. Other investigations concerning nurses' and nursing assistants' restraint use perceptions reported significant differences according to variables such as receiving postgraduate education and the wards in which they work (16).

We consider it important to design postgraduate education programs that cover reasons for restraint use, its ethical and legal aspects, and alternative substitute methods to raise nurses' awareness on the issue. The perception of restraint use does not appear to be affected by education in geriatric nursing. As our study did not provide any information about the nature or degree of the extra knowledge of general nursing practice, this issue is open to research.

In conclusion, this study provided the clinical outcomes of nurses' perceptions on the practice of physical restraint in Turkey. The overall PRUQ score of the sample was found to be 4.14. There was a statistically significant difference between the scores of the perceptions of the wards and ICU nurses. The most important reasons for the participants to use restraint were found to be protection of an older person from falling out of bed, preventing an older person from breaking open sutures, and pulling out a catheter and/or a feeding tube. Reasons that are less important, according to the subjects, included preventing an older person from taking things from others, substituting for staff observation, and providing quiet time.

Although restraint use is a practice applied for patient safety, it should be considered that this procedure can limit patient freedom and have effects that may even lead to death. Decision about restraint use should involve the evaluation of the expected benefits or risks as well as potential side effects. It is important to plan individualized nursing care for the patient who is restrained and to provide him and his family with the opportunity to participate in achieving the safety of the patient. In cases where the decision to use restraint has been made, the reasons for restraint use should be clarified, the application period should be limited, and the reasons, efficacy, and side effects of the practice should be reported for each patient. Prior to restraint use, the relatives of the agitated, aggressive, or dementia patient should be informed and consent should be obtained.

\section{Limitations of the study}

The data in this study were obtained from nurses recruited from one hospital in Turkey, which limits the generalizability of the findings. Future research requires larger samples to ensure representativeness.

\section{Conflict of interest}

The authors declare that there is no conflict of interest.

\section{Funding}

This research received no grant from any funding agency in the public, commercial, or notfor-profit sectors. 


\section{REFERENCES}

1. Allen D, Lowe K, Brophy S, Moore K. Predictors of restrictive reactive strategy use in people with challenging behaviour. JARID 2009;22(2):159-68.

2. Arai F, Leibowitz SY. Nurses' perceptions of restraint. The Japan Society of Nursing Research 2014; 5:39-46.

3. Bray K, Hill K, Robson W, et al. British association of critical care nurses position statement on the use of restraint in adult critical care units. Nurs Crit Care 2004;9(5):199-212. (PMID:15462118).

4. Chang LY, Wang KW, Chao YF. Influence of physical restraint on unplanned extubation of adult intensive care parents: a case control study. Am J Crit Care 2008;17(5):408-15. (PMID:18775996).

5. Cotter VT. Restraint free care in older adults with dementia. Keio J Med 2005;54(2):80-4. (PMID:16077257).

6. Evans LK, Strumpf NE. Frailty and physical restraint. In: Perry HM, Morley JE, Coe RM.(Eds). Aging and musculoskeletal disorders. Springer, New York 1993, pp 324-33.

7. Fariña-López E, Estévez-Guerra GJ, Gandoy-Crego M, Polo-Luque LM, Gómez-Cantorna C, Capezuti EA. Perception of spanish nursing staff on the use of physical restraints. J Nurs Scholarsh 2014;46(5):32230. (PMID:24754778).

8. Fradkin $M$, Kidron D, Hendel T. Israeli student nurses' attitudes about physical restraints in acute care settings. Geriatr Nurs 1999;20(2):101-5. (PMID:10382427).

9. Gallinagh R, Slevin E, Mccormack B. Side rails as physical restraints in the care of older people: a management issue. J Nurs Manag 2002;10(5):299306. (PMID:12191076).

10. Hamers JP, Meyer G, Köpke S, Lindenmann R, Groven R, Huizing AR. Attitudes of Dutch, German and Swiss nursing staff towards physical restraint use in nursing home residents, a cross-sectional study. Int J Nurs Stud 2009;46(2):248-55. (PMID:18656876).

11. Helmuth AM. Nurses' Attitudes toward older persons on their use of physical restraints. Orthop Nurs 1995;14(2):43-51. (PMID:7761132).

12. Huang $H C$, Huang $Y T$, Lin KC, Kuo YF. Risk factors associated with physical restraints in residential aged care facilities: a community-based epidemiological survey in Taiwan. J Adv Nurs 2013;70(1):130-43. (PMID:23734585).
13. Irving, K. Inappropriate restraint practices in Australian teaching hospitals. Aust J Adv Nurs. 2004;21(4):23-7. (PMID:18646650).

14. Jiang $\mathrm{H}$, Li C, Gu Y, He Y. Nurses' perceptions and practice of physical restraint in China. Nurs Ethics 2015:22(6):652-60. (PMID:25488757).

15. Kapo J, Morrison LJ, Liao S. Palliative care for the older adult. J Palliat Med 2007;10(1):185-209. (PMID:17298269).

16. Koczy P, Becker C, Rapp K, et al. Effectiveness of a multifactorial intervention to reduce physical restraints in nursing home residents. J Am Geriatr Soc 2011;59(2):333-9. (PMID:21314651).

17. Luiselli JK. Physical restraint of people with intellectual disability: a review of implementation reduction and elimination procedures. JARID 2009;22(2):126-34.

18. McGabe DE, Alvarez CD, Mcnulty SR, Fitzpatrick JJ. Perceptions of physical restraints use in the elderly among registered nurses and nurse assistants in a single acute care hospital. Geriatr Nurs 2011;32(1):3945. (PMID:21146901).

19. Myers $H$, Nikoletti $S$, Hill A. Nurses' use of restraints and their attitudes toward restraint use and the elderly in an acute care setting. Nurs Health Sci 2001;3(1):29-34. (PMID:11882175).

20. Ozkan SA, Karaca T, Ister ED. Validity and reliability of the "perceptions of restraint use questionnaire" for use in Turkey. Journal of Turkish Geriatrics 2017;20(1):30-7.

21. Shorr RI, Guillen MK, Rosenblatt LC, Walker K, Caudle CE, Kritchevsky SB. Restraint use, restraint orders, and the risk of falls in hospitalized patients. J Am Geriatr Soc 2002;50(3):526-9. (PMID:11943051).

22. Sloane PD, Zimmerman S, Williams CS, Hanson LC. Dying with dementia in long-term care. Gerontologist 2008;48(6):741-51. (PMID:19139248).

23. Strumpf NE, Evans LK. Physical Restraint of the Hospitalized Elderly. Nurs Res 1988;37(3):132-7. (PMID:3368353).

24. Sturmey P. It is time to reduce and safely eliminate restrictive behavioural practices. JARID 2009;22(2):105-10.

25. Vassallo M, Wilkinson C, Stockdale R, Malik N, Baker $\mathrm{R}$, Allen S. Attitudes to restraint for the prevention of falls in hospital. Gerontology 2004;51(1):66-70. (PMID:15591759). 